\title{
Perbandingan Efek Pemberian Norepinefrin Bolus Intravena dengan Norepinefrin Infus Kontinu dalam Tatalaksana Hipotensi, Laju Nadi, dan Nilai APGAR pada Seksio Sesarea dengan Anestesi Spinal
}

\author{
Fitri Sepviyanti Sumardi, ${ }^{1}$ Abdul Muthalib Nawawi, ${ }^{2}$ Tinni T. Maskoen ${ }^{2}$ \\ ${ }^{1}$ Bagian Anestesiologi dan Terapi Intensif Rumah Sakit Bayukarta Karawang, \\ ${ }^{2}$ Departemen Anestesiologi dan Terapi Intensif \\ Fakultas Kedokteran Universitas Padjadjaran/Rumah Sakit Dr. Hasan Sadikin Bandung
}

\begin{abstract}
Abstrak
Vasopresor sering digunakan dalam tatalaksana hipotensi anestesi spinal pada seksio sesarea. Penelitian bertujuan membandingkan efek pemberian norepinefrin bolus intravena dengan norepinefrin infus kontinu dalam tatalaksana hipotensi pada anestesi spinal pasien seksio sesarea dan pengaruh pada laju nadi serta nilai APGAR. Penelitian bersifat eksperimental acak tersamar ganda pada 44 ibu hamil status fisik American Society of Anesthesiologist (ASA) II yang menjalani seksio sesarea dengan anestesi spinal di Rumah Sakit Dr. Hasan Sadikin Bandung pada September-November 2013. Subjek penelitian dibagi menjadi 2 kelompok yaitu kelompok norepinefrin bolus intravena $4 \mu \mathrm{g}(\mathrm{NB})$ dan kelompok norepinefrin infus kontinu $8 \mu \mathrm{g} / \mathrm{menit}$ (NK). Data dianalisis dengan uji-t, Uji Mann-Whitney, chi-kuadrat dan uji-t analysis of variance (ANOVA), nilai $\mathrm{p}<0,05$ dianggap bermakna. Hasil penelitian menunjukkan bahwa peningkatan tekanan darah sistol, diastol, dan rata-rata lebih tinggi pada kelompok NB $(\mathrm{p}=0,000)$. Perubahan laju nadi secara umum pada kedua kelompok relatif stabil dan nilai APGAR menunjukkan perbedaan yang tidak bermakna $(p>0,05)$. Simpulan penelitian ini adalah kedua cara pemberian norepinefrin ini dapat digunakan dalam tatalaksana hipotensi anestesi spinal tanpa memengaruhi laju nadi dan nilai APGAR.
\end{abstract}

Kata kunci: Anestesi spinal, hipotensi, nilai APGAR, norepinefrin, seksio sesarea

\section{Effect of Intravenous Norepinephrine Bolus and Norepinephrine Continuous Infusion on Hypotension Management, Heart Rate, and APGAR Score in Caesarean Section Patient under Spinal Anesthesia}

\begin{abstract}
Vasopresors are commonly used for the treatment of hypotension in spinal anesthesia for cesarean section. This research aimed to compare intravenous bolus of norepinephrine to continuous infusion of norepinephrine effectiveness in hypotension management in caesarean section patient under spinal anesthesia and their effect on heart rate and APGAR Score, The experimental study was conducted in a double-blind randomized manner to 44 American Society of Anesthesiologist (ASA) physical status II pregnant women undergoing cesarean section with spinal anesthesia in Dr. Hasan Sadikin General Hospital Bandung within the period of September to -November 2013. The Study subjects were grouped into two groups, the first group received $4 \mu \mathrm{g}$ intravenous bolus of norepinephrine group (NB) and and the second received $8 \mu \mathrm{g} /$ minute continuous infusion of norepinephrine group (NK). Data were analyzed by t-test, Mann-Whitney test, chi-square and analysis of variance (ANOVA) t-test with $p<0.05$ was considered significant. The results showed that the increase in systolic, diastolic and mean arterial blood pressures were higher in the NB group $(p=0.000)$. Changes in heart rate were generally relatively stable in both groups and APGAR score showed a non-significant difference $(p>0.05)$. Conclusion from this study is the administration of norepinephrine in both ways can be used for the treatment of hypotension of spinal anesthesia without affecting the heart rate and APGAR score
\end{abstract}

Key words: APGAR score, caesarean section, hypotension, norepinephrine, spinal anaesthesia

Korespondensi: Fitri Sepviyanti Sumardi, dr., SpAn, Bagian Anestesiologi dan Terapi Intensif Rumah Sakit Bayukarta Karawang,Jl.LesmanaNo.10Bandung,Tlp 022-6018423,Mobile081323018558,Emailfitrisepviyantisumardi@gmail.com 


\section{Pendahuluan}

Seksio sesarea biasa dilakukan dengan teknik anestesia spinal yang memungkinkan pasien tetap terjaga selama pembedahan, hal ini akan mengurangi kemungkinan terjadi pneumonitis aspirasi pada ibu serta masalah penyulit lain, seperti kegagalan membebaskan jalan napas saat dilakukan anestesia umum. Selain itu, hasil luaran nilai appearance pulse grimace activity respiration (APGAR) lebih baik serta hasil tes neurobehavioral yang lebih tinggi, pemberian anestesi spinal menghindari depresi neonatal dibandingkan dengan anestesia umum. ${ }^{1}$

Kerugian anestesia spinal untuk ibu adalah kejadian hipotensi. Kejadian hipotensi pada ibu akan menyebabkan hipoperfusi uteroplasenta dan memicu kejadian penurunan aliran darah intervili akut dengan potensi terjadi asidosis janin. ${ }^{1}$ Kejadian hipotensi setelah pemberian anestesi spinal untuk seksio sesarea ditemukan sampai 90\%. Pergeseran rahim ke kiri adalah tindakan rutin, sedangkan pemberian cairan sebelum dilakukan tindakan anestesia regional masih merupakan kontroversi pada banyak penelitian. ${ }^{2,3}$ Meskipun tindakan konservatif di atas telah dilakukan dengan baik, pemberian obat-obat vasopresor tetap diperlukan untuk tatalaksana hipotensi. ${ }^{2,4}$

Saat ini efedrin serta fenilefrin merupakan vasopresor pilihan untuk mencegah dan juga tatalaksana hipotensi akibat blok spinal pada seksio sesarea, namun fenilefrin tidak tersedia secara luas di beberapa negara termasuk di Indonesia.Saatini efedrin menjadi standarbaku lini pertama untuk tatalaksana hipotensi pada kasus-kasus anestesia obstetrik karena aman dipergunakan, kemudahan untuk didapatkan, serta sering digunakan oleh dokter anestesia. Efek efedrin bukan hanya akan meningkatkan kontraktilitas otot, detak, serta curah jantung melalui reseptor- $\beta 1$, namun vasokonstriksi perifer serta peningkatan tekanan darah juga terjadi melalui aktivasi reseptor- $\alpha .{ }^{5}$ Sampai saat ini, efedrin kadang-kadang tidak tersedia di Indonesia dengan alasan yang tidak jelas.

Pada kondisi efedrin yang tidak tersedia, maka perlu dicari obat lain yang mempunyai efek seperti efedrin untuk mempertahankan aliran darah uterus sehingga mempertahankan perfusi plasenta pada saat terjadi penurunan tekanan darah akibat anestesia spinal pada saat dilakukan seksio sesarea. Pada penelitian yang dilakukan pada tahun 2010 menyatakan bahwa penggunaan fenilefrin dinilai memiliki kelebihan dibandingkan dengan efedrin untuk mengatasi hipotensi sebagai akibat anestesia spinal pada seksio sesarea. ${ }^{1}$ Tiga penelitian tentang norepinefrin terhadap mikrosirkulasi, fungsi ventrikel kiri, serta plasenta manusia, menunjukkan hasil bahwa norepinefrin dapat dipergunakan sebagai vasopresor pengganti fenilefrin dengan beberapa keunggulan..$^{5-7}$

Penelitian lain tahun 1965 membandingkan efek kardiovaskular pemberian efedrin $8 \mathrm{mg} /$ menit dengan norepinefrin $0,008 \mathrm{mg} /$ menit didapat hasil bahwa norepinefrin $0,008 \mathrm{mg} /$ menit menaikkan tekanan darah sama efektif dengan efedrin $8 \mathrm{mg} / \mathrm{menit}$. Pada penelitian ini peneliti menganjurkan dosis norepinefrin $0,008 \mathrm{mg} / \mathrm{menit}$ sebagai alternatif tatalaksana hipotensi pada anestesia spinal. ${ }^{8}$

Hasil penelitian yang dipublikasikan tahun 1993, bolus intravena norepinefrin 0,1 $\mu \mathrm{g} /$ kgBB sebanding dengan fenilefrin $2 \mu \mathrm{g} / \mathrm{kgBB}$ dalam meningkatkan tekanan darah rata-rata dengan hanya sedikit pengaruhnya terhadap laju nadi. ${ }^{7}$ Pada suatu penelitian tahun 2010 yang membandingkan norepinefrin $0,88 \mu \mathrm{g} /$ kgBB dengan efedrin 9,7 mg dalam tatalaksana hipotensi pada anestesi spinal didapatkan hasil bahwa norepinefrin $0,88 \mu \mathrm{g} / \mathrm{kgBB}$ sama efektif dengan efedrin 9,7 mg dalam mengembalikan tekanan darah setelah terjadi hipotensi pada anestesi spinal. $^{5}$

Hasil penelitian lain menunjukkan bahwa tekanan perfusi arteri pada janin (fetal arterial pressure/FAP) meningkat akibat pemberian fenilefrin, namun efedrin memberikan hasil yang tidak dapat diprediksi, dan norepinefrin tidak menunjukkan perubahan terhadap FAP. ${ }^{6}$ Penelitianinimenunjukkanbahwanorepinefrin dapat digunakan sebagai vasopresor alternatif karena tidak menurunkan FAP. Dua kelebihan norepinefrin bila dibandingkan dengan efedrin yaitu kemungkinan kecil terjadi asidosis janin, dan juga kemudahan pemberian secara titrasi untuk bisa mencapai tekanan darah rata-rata/ 
mean arterial pressure (MAP) yang diinginkan dalam waktu singkat.

Norepinefrin (NE) telah sering digunakan untuk meningkatkan tekanan darah karena anestesia spinal. Cara yang digunakan adalah dengan memberikan norepinefrin secara titrasi memakai infus kontinu dengan melarutkan norepinefrin dalam $100 \mathrm{~mL}$ larutan dekstrose $5 \%$. Pemberian dengan cara demikian akan berefek pada biaya yang menjadi sangat mahal. Pemberian bolus intravena dengan melarutkan $4 \mathrm{~mL}$ norepinefrin dalam $500 \mathrm{~mL}$ dekstrose $5 \%$ dengan dosis 0,004 mg akan lebih hemat, tetapi belum diketahui efek terhadap tekanan darah dan laju nadi.

\section{Subjek dan Metode}

Penelitianini bertujuan untukmembandingkan efek pemberian norepinefrin bolus intravena $4 \mu \mathrm{g}(\mathrm{NB})$ dengan norepinefrin infus kontinu $8 \mu \mathrm{g} /$ menit dalam hal menurunkan kejadian hipotensi setelah anestesia spinal pada seksio sesarea, dan pengaruhnya terhadap laju nadi serta nilai APGAR bayi. Subjek penelitian ini adalah wanita hamil yang dilakukan seksio sesarea di Rumah Sakit Dr. Hasan Sadikin Bandung yang telah memenuhi kriteria inklusi serta tidak termasuk eksklusi. Kriteria inklusi adalah pasien wanita hamil aterm, usia 18-40 tahun yang dilakukan seksio sesarea dengan anestesia spinal, status fisik American's Society of Anesthesiologist (ASA) II dan juga bersedia mengikuti penelitian serta menandatangani (informed consent). Kriteria eksklusi adalah tinggi badan $<150 \mathrm{~cm}$, kehamilan risiko tinggi, kehamilan gemeli, hipertensi, serta hipotensi dengan tekanan darah sistol (TDS) $<100 \mathrm{mmHg}$ atau bila ada kontraindikasi dilakukan anestesi spinal, obat anestesi lokal dan norepinefrin. Kriteria pengeluaran apabila terjadi kegagalan tindakan spinal setelah ditunggu 15 menit.

Penelitian ini adalah eksperimental dengan melakukan uji klinis rancangan acak lengkap terkontrol butaganda (double blind randomized controlled trial). Ukuran sampel ditentukan dengan mempergunakan formula uji hipotesis dua rata-rata dengan memperhitungkan drop out sebesar $10 \%$ sehingga didapatkan jumlah sampel yang dibutuhkan ialah 22 subjek untuk setiap kelompok, total sampel 44 orang.

Analisis statistika terhadap hasil penelitian menggunakan uji-t tidak berpasangan apabila data berdistribusi normal, dengan alternatif Uji Mann-Whitney bila data tidak normal, dan uji chi-kuadrat untuk data kategorik, dengan tingkat kepercayaan adalah 95\% dan dianggap bermakna bila $\mathrm{p}<0,05$. Uji analysis of variance (ANOVA) digunakan untuk melakukan analisis pada sejumlah sampel dengan jumlah data yang sama pada tiap kelompok, atau dengan jumlah data yang berbeda, dianggap bermakna jika nilai distribusi $\mathrm{F}_{\text {hitung }} \leq \mathrm{F}_{\text {tabel }}$. Data disajikan dalam rata-rata (mean) dan dianalisis dengan menggunakan program statistical product and service solution (SPSS) 21,0 for windows.

Saat pasien telah berada di kamar operasi dilakukan pemasangan jalur vena dan alat-alat pemantau, diberikan cairan preloading Ringer laktat (RL) $15 \mathrm{~mL} / \mathrm{kgBB}$ dalam waktu 20 menit. Kemudian dilakukan anestesia spinal dengan 2 $\mathrm{mL}$ bupivakain heavy $0.5 \%$ ditambah fentanil $25 \mu \mathrm{g}$. Saat selesai penyuntikan dipakai sebagai awal perhitungan waktu, selanjutnya pasien dibaringkan dalam posisi telentang horizontal, diberi ganjal di panggul kanan, dengan kepala diberi bantal dan oksigen $2 \mathrm{~L} /$ menit per nasal. Setelah itu dilakukan penilaian efektivitas blokade sensorik dan motorik. Pasien dibagi ke dalam 2 (dua) kelompok, yaitu kelompok I yang diberikan norepinefrin bolus intravena 4 $\mu \mathrm{g}$ dan kelompok II diberi norepinefrin $8 \mu \mathrm{g} /$ menit ketika terjadi penurunan tekanan darah sebesar 20\% setelah anestesia spinal. Variabel hemodinamik diukur dan dicatat setiap menit selama 15 menit pertama, kemudian tiap tiga menit sampai dengan operasi berakhir. Selama operasi berlangsung, tekanan darah sistol, diastol, rata-rata, laju nadi, induction-delivery time, uterine insicion-delivery time, serta nilai APGAR dicatat. Apabila tetap terjadi hipotensi maka diberikan bolus efedrin $5 \mathrm{mg}$ intravena, bila terjadi bradikardia maka diberikan sulfas atropin intravena $0,5 \mathrm{mg}$. Setelah bayi lahir ibu diberikan oksitosin drip 10 IU dalam $500 \mathrm{~mL}$ cairan Ringer laktat sebanyak 10-15 tetes per menit. 
Tabel 1 Perbandingan Tekanan Darah pada Kedua Kelompok Perlakuan

\begin{tabular}{|c|c|c|c|}
\hline \multirow{2}{*}{ Waktu } & Norepinefrin Bolus & Norepinefrin Kontinu & \multirow{2}{*}{ Nilai p } \\
\hline & $\bar{X}(S D)$ & $\bar{X}$ (SD) & \\
\hline Prainduksi & $85,67(3,49)$ & $84,53(2,23)$ & 0,206 \\
\hline Menit ke-1 & $79,62(3,65)$ & $79,77(2,25)$ & 0,869 \\
\hline Menit ke-2 & $73,97(3,66)$ & $74,99(1,92)$ & 0,257 \\
\hline Menit ke-3 & $67,24(2,24)$ & $61,50(1,84)$ & $0,000 *$ \\
\hline Menit ke-4 & $89,79(2,73)$ & $64,89(1,58)$ & $0,000^{*}$ \\
\hline Menit ke-5 & $81,48(4,72)$ & $64,30(1,02)$ & $0,000 *$ \\
\hline Menit ke-6 & $83,35(4,55)$ & $65,74(1,14)$ & $0,000^{*}$ \\
\hline Menit ke-7 & $81,38(2,75)$ & $65,86(1,44)$ & $0,000 *$ \\
\hline Menit ke-8 & $83,97(5,14)$ & $66,74(1,09)$ & $0,000^{*}$ \\
\hline Menit ke-9 & $85,23(4,29)$ & $70,32(1,61)$ & $0,000 *$ \\
\hline Menit ke-10 & $82,99(4,03)$ & $70,82(2,04)$ & $0,000 *$ \\
\hline Menit ke-11 & $83,03(3,91)$ & $70,03(2,17)$ & $0,000 *$ \\
\hline Menit ke-12 & $85,41(3,77)$ & $68,67(1,92)$ & $0,000^{*}$ \\
\hline Menit ke-13 & $85,67(4,22)$ & $69,53(2,09)$ & $0,000 *$ \\
\hline Menit ke-14 & $85,62(2,69)$ & $70,80(1,74)$ & $0,000^{*}$ \\
\hline Menit ke-15 & $82,55(3,39)$ & $70,04(2,58)$ & $0,000 *$ \\
\hline Menit ke-18 & $85,30(2,98)$ & $71,33(2,26)$ & $0,000^{*}$ \\
\hline Menit ke-21 & $85,06(3,52)$ & $73,38(2,08)$ & $0,000^{*}$ \\
\hline Menit ke-24 & $84,49(3,10)$ & $71,74(2,16)$ & $0,000 *$ \\
\hline Menit ke-27 & $83,93(3,30)$ & $72,18(2,84)$ & $0,000 *$ \\
\hline Menit ke-30 & $87,39(3,00)$ & $73,08(2,58)$ & $0,000^{*}$ \\
\hline Menit ke-33 & $86,96(2,24)$ & $81,11(2,65)$ & $0,000 *$ \\
\hline Menit ke-36 & $86,73(2,45)$ & $86,79(1,51)$ & 0,920 \\
\hline Menit ke-39 & $87,05(1,99)$ & $86,79(1,51)$ & 0,631 \\
\hline Menit ke-42 & $86,65(2,37)$ & $87,12(1,51)$ & 0,439 \\
\hline Menit ke-45 & $86,56(3,22)$ & $87,14(1,53)$ & 0,454 \\
\hline Menit ke-48 & $86,58(2,35)$ & $87,15(1,51)$ & 0,341 \\
\hline Menit ke-51 & $86,8(2,48)$ & $87,17(1,51)$ & 0,559 \\
\hline Menit ke-54 & $86,02(2,77)$ & $87,17(1,51)$ & 0,097 \\
\hline Menit ke-57 & $86,50(2,50)$ & $87,17(1,51)$ & 0,293 \\
\hline Menit ke-60 & $86,15(2,76)$ & $87,17(1,51)$ & 0,141 \\
\hline Nilai-p ${ }^{2)}$ & $0,000^{*}$ & $0,000^{*}$ & \\
\hline
\end{tabular}

Keterangan: 1) Nilai p diperoleh berdasarkan uji-t independen, 2) Nilai p diperoleh berdasarkan uji-t ANOVA. *) perbedaan bermakna jika $\mathrm{p}<0,05$

Penelitian dilakukan di Central Operating Theatre (COT) Rumah Sakit Dr. Hasan Sadikin Bandung. Pengumpulan data dilakukan sejak disetujui oleh Komite Etik Penelitian dan Kesehatan Fakultas Kedokteran Universitas Padjajaran/Rumah Sakit Dr. Hasan Sadikin dari 
Tabel 2 Perbandingan Laju Nadi pada Kedua Kelompok Perlakuan

\begin{tabular}{|c|c|c|c|}
\hline \multirow{2}{*}{ Waktu } & Norepinefrin Bolus & Norepinefrin Kontinu & \multirow{2}{*}{ Nilai p } \\
\hline & $\bar{X}(S D)$ & $\bar{X}(S D)$ & \\
\hline Prainduksi & $83,45(3,66)$ & $82,45(2,58)$ & 0,301 \\
\hline Menit ke-1 & $82,18(3,79)$ & $81,45(3,90)$ & 0,534 \\
\hline Menit ke-2 & $80,27(3,91)$ & $80,77(2,98)$ & 0,635 \\
\hline Menit ke-3 & $58,45(2,69)$ & $57,68(1,96)$ & 0,283 \\
\hline Menit ke-4 & $75,36(8,53)$ & $71,86(5,92)$ & 0,122 \\
\hline Menit ke-5 & $72,09(7,03)$ & $70,64(8,10)$ & 0,528 \\
\hline Menit ke-6 & $70,14(7,87)$ & $72,95(7,79)$ & 0,239 \\
\hline Menit ke-7 & $73,32(7,78)$ & $75,45(6,62)$ & 0,332 \\
\hline Menit ke-8 & $76,68(5,76)$ & $74,64(4,60)$ & 0,201 \\
\hline Menit ke-9 & $68,64(6,64)$ & $71,91(7,78)$ & 0,141 \\
\hline Menit ke-10 & $73,32(7,88)$ & $70,05(6,40)$ & 0,138 \\
\hline Menit ke-11 & $73,36(6,67)$ & $71,91(3,56)$ & 0,373 \\
\hline Menit ke-12 & $71,27(7,43)$ & $67,27(8,47)$ & 0,103 \\
\hline Menit ke-13 & $74,45(6,43)$ & $72,36(7,08)$ & 0,311 \\
\hline Menit ke-14 & $60,68(3,21)$ & $59,82(3,39)$ & 0,391 \\
\hline Menit ke-15 & $66,91(6,28)$ & $63,86(4,54)$ & 0,072 \\
\hline Menit ke-18 & $70,09(8,25)$ & $68,32(6,46)$ & 0,432 \\
\hline Menit ke-21 & $68,18(5,82)$ & $71,00(7,32)$ & 0,165 \\
\hline Menit ke-24 & $67,82(6,27)$ & $72,32(8,99)$ & 0,062 \\
\hline Menit ke-27 & $69,86(4,74)$ & $66,68(7,17)$ & 0,091 \\
\hline Menit ke-30 & $70,68(5,20)$ & $67,41(6,57)$ & 0,074 \\
\hline Menit ke-33 & $71,27(5,11)$ & $67,86(7,61)$ & 0,089 \\
\hline Menit ke-36 & $73,09(4,55)$ & $70,18(7,11)$ & 0,115 \\
\hline Menit ke-39 & $72,18(7,74)$ & $69,55(8,47)$ & 0,287 \\
\hline Menit ke-42 & $67,64(6,82)$ & $67,00(2,93)$ & 0,691 \\
\hline Menit ke-45 & $74,73(8,11)$ & $72,32(6,83)$ & 0,293 \\
\hline Menit ke-48 & $72,00(7,12)$ & $68,64(6,43)$ & 0,108 \\
\hline Menit ke-51 & $69,86(8,63)$ & $67,91(6,01)$ & 0,388 \\
\hline Menit ke-54 & $72,09(7,48)$ & $67,50(8,09)$ & 0,057 \\
\hline Menit ke-57 & $75,82(7,26)$ & $71,23(8,33)$ & 0,058 \\
\hline Menit ke-60 & $69,00(4,78)$ & $66,55(7,94)$ & 0,222 \\
\hline Nilai-p & $0,000^{*}$ & $0,000^{*}$ & \\
\hline
\end{tabular}

Keterangan: 1) Nilai p diperoleh berdasarkan uji-t independen, 2) Nilai p diperoleh berdasarkan uji-t ANOVA.

*) perbedaan bermakna jika $\mathrm{p}<0,05$.

bulan September sampai dengan November 2013.

\section{Hasil}

Perbandingan data-data karakteristik umum 


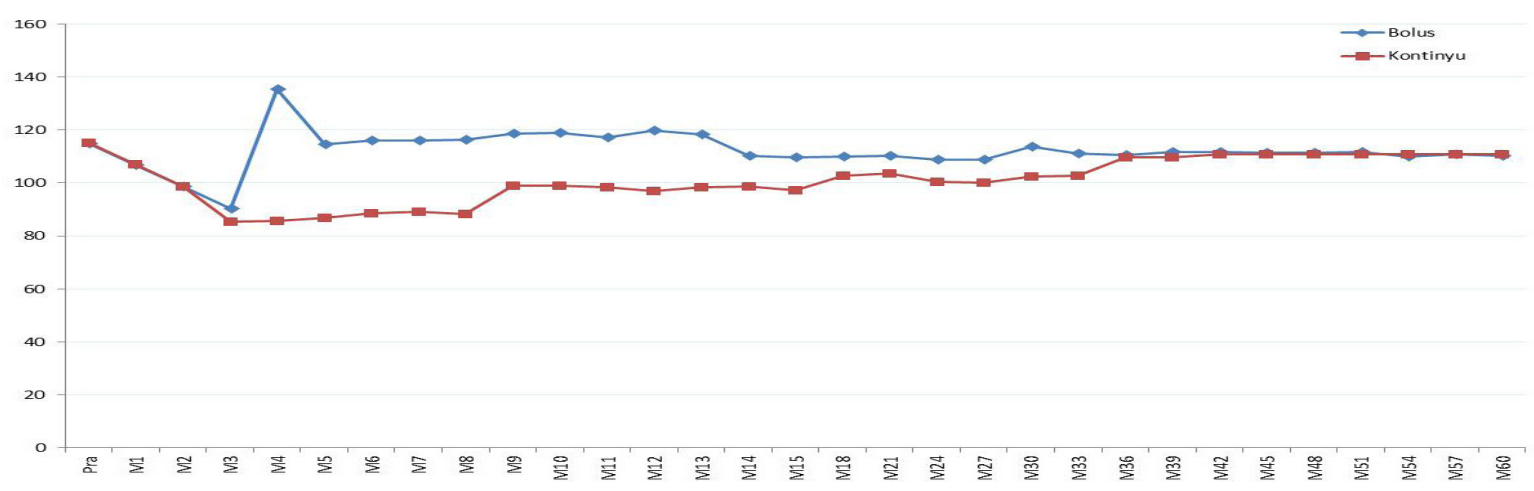

Gambar 1 Grafik Perbandingan Tekanan Darah pada Kedua Kelompok Perlakuan

antara subjek penelitian pada kedua kelompok berdasarkan uji-t independen pada pengujian statistika untuk faktor usia, berat badan, tinggi badan, tekanan darah sistol, diastol, dan ratarata, serta uji chi-kuadrat pada usia kehamilan (karena berbentuk kategori: aterm/parturien) menunjukkan bahwa tidak terdapat perbedaan bermakna $(p>0,05)$, sehingga kedua kelompok dianggap relatif homogen serta layak untuk dibandingkan.

Ketinggian efek blokade antara kelompok NB dan NK tidak berbeda secara bermakna ( $p>0,05)$, dengan kecenderungan kelompok NB maupun NK mayoritas berada di T6-T8. Lama preloading kedua kelompok tidak berbeda secara bermakna $(p>0,05)$, dengan rata-rata keduanya pada angka 20 menit. Demikian pula jumlah preloading kedua kelompok berkisar pada 902-943 $\mathrm{mL}$, dengan perbedaan tidak bermakna.
Efek norepinefrin (NE) terhadap tekanan darah berdasarkan tekanan darah rata-rata menunjukkan bahwa mulai prainduksi hingga menit kedua, tekanan darah kedua kelompok tidaklah berbeda secara bermakna $(p>0,05)$. Kejadian hipotensi sebagai akibat pemberian anestesia spinal terjadi pada saat menit ketiga, dengan penurunan sebesar $20 \%$ dari tekanan darah awal. Mulai menit ke-4 hingga menit ke33 tekanan darah kelompok bolus lebih tinggi bila dibandingkan dengan kelompok kontinu, dengan perbedaan yang bermakna, dengan tren tekanan darah kelompok kontinu cenderung meningkat. Sejak menit ke-36 hingga menit ke-60, tekanan darah pada kelompok kontinu cenderung terus meningkat dan menjadi tidak berbeda bermakna dengan kelompok bolus. Hasil Uji ANOVA menunjukkan perbedaan tekanan darah pada setiap perlakuan waktu menunjukkan perbedaan bermakna, baik pada

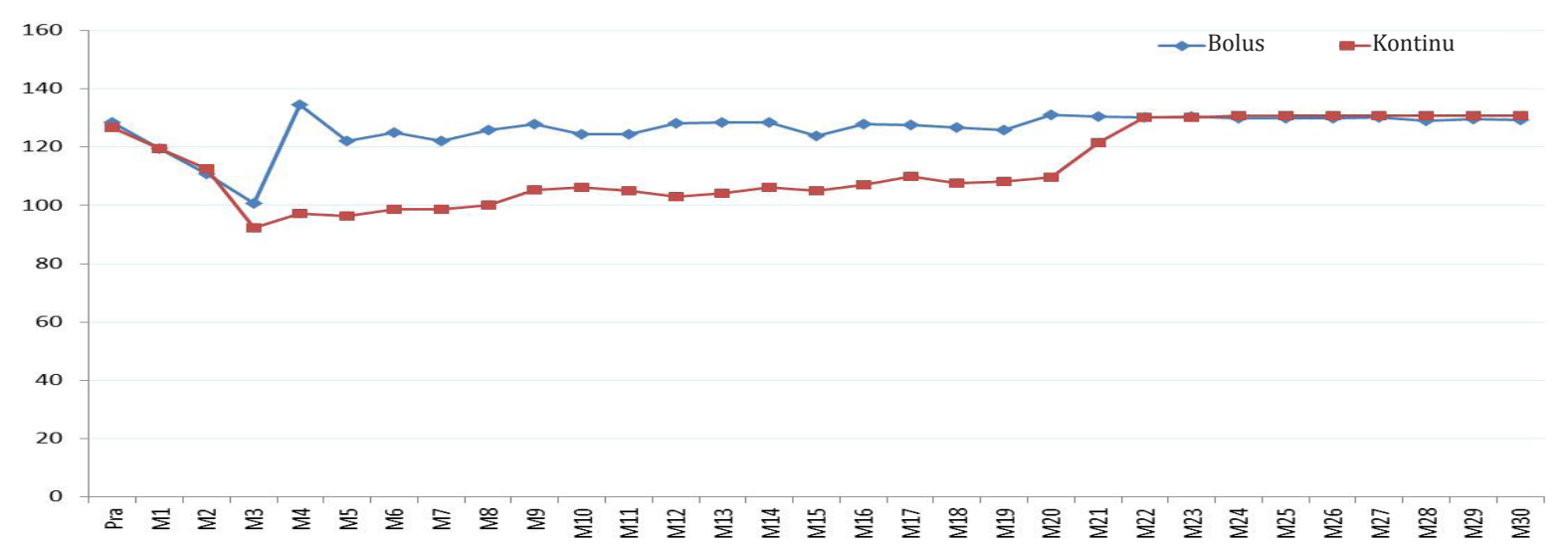

Gambar 2 Grafik Perbandingan Laju Nadi pada Kedua Kelompok Perlakuan 
Tabel 3 Perbandingan Nilai APGAR

\begin{tabular}{lccc}
\hline \multicolumn{1}{c}{ Nilai APGAR } & $\begin{array}{c}\text { Norepinefrin Bolus } \\
(\mathbf{n = 2 2})\end{array}$ & $\begin{array}{c}\text { Norepinefrin Kontinu } \\
(\mathbf{n = 2 2})\end{array}$ & Nilai p \\
\hline APGAR 1 menit & 1 & 4 & 0,250 \\
6 & 5 & 7 & \\
7 & 13 & 7 & \\
8 & 3 & 4 & 0,475 \\
9 & & & \\
APGAR 5 menit & 1 & 2 & \\
8 & 11 & 12 & \\
9 & 10 & 8 & \\
10 & & & \\
\hline
\end{tabular}

Keterangan: nilai APGAR 1 dan 5 menggunakan Uji Mann-Whitney. Perbedaan bermakna jika p<0,05

kelompok bolus maupun kelompok kontinu ( $\mathrm{p}<0,05$; Tabel 1; Gambar 1).

Berdasarkan hasil Uji ANOVA, perubahan laju nadi terhadap setiap perlakuan waktu menunjukkan perbedaan yang bermakna pada kedua kelompok perlakuan $(\mathrm{p}<0,05$; Tabel 2; Gambar 2). Hal ini menunjukkan bahwa terjadi perubahan laju nadi sejak awal pengamatan (menit ke-1) hingga akhir pengamatan (menit ke-60), namun pada dua kelompok perlakuan perbedaan tersebut tidak bermakna $(\mathrm{p}>0,05$; Tabel 2; Gambar2).

Nilai APGAR 1 menit pada kedua kelompok perlakuan tidak menunjukkan perbedaan yang bermakna $(p>0,05)$, dengan kecenderungan dominan kedua kelompok pada skala APGAR 8. Nilai APGAR 5 menit pada kedua kelompok perlakuan tidak menunjukkan perbedaan yang bermakna $(p>0,05)$, dengan kecenderungan dominan kedua kelompok pada skala APGAR 9 (Tabel 3).

Penghitungan terhadap Induction-delivery time (ID), uterine insicion-delivery time (UD), dan juga lama operasi menunjukkan tidak ada perbedaan bermakna $(p>0,05)$ antara kedua kelompok (Tabel 4).

\section{Pembahasan}

Penelitian ini dilakukan untuk mengetahui pengaruh norepinefrin ( $\alpha$-adrenergik dan juga $\beta 1$ ) dalam penatalaksanaan hipotensi maternal sebagai efek anestesia spinal, yang dapat mengancam kehidupan ibu dan juga janin bila tidak dikoreksi. Keadaan hipotensi maternal walaupun terjadi dalm waktu yang singkat, dapat menyebabkan penurunan nilai APGAR, bahkan dapat menimbulkan asidosis

Tabel 4 Perbandingan Induction-delivery Time, Uterine Insicion-delivery Time, dan Lama Operasi

\begin{tabular}{lccc}
\hline \multicolumn{1}{c}{ Variabel } & $\begin{array}{c}\text { Norepinefrin Bolus } \\
(\mathbf{n = 2 2})\end{array}$ & $\begin{array}{c}\text { Norepinefrin Kontinu } \\
(\mathbf{n = 2 2})\end{array}$ & Nilai p \\
\hline ID (menit) & 7,14 & 7,09 & 0,860 \\
UD (detik) & 89,09 & 87,73 & 0,798 \\
Lama operasi (menit) & 106,82 & 104,73 & 0,516 \\
\hline
\end{tabular}

Keterangan: nilai p diperoleh dengan uji-t independen. Perbedaan bermakna jika $p<0,05$ 
bila kejadian hipotensi maternal berlangsung lama. Bila hipotensi tidak lebih dari dua menit, asidosis janin minimal dan tidak memengaruhi neurobehavioral bayi baru lahir.,10

Pada penelitian ini dari karakteristik umum subjek, ketinggian blokade anestesia spinal, lama preloading, dan jumlah cairan preloading tidak ada perbedaan yang bermakna menurut statistika $(p>0,05)$, sehingga menyingkirkan semua faktor yang dapat memerberat kejadian hipotensi pada anestesi spinal, karena fisiologi dan juga anatomi pada wanita hamil berbeda dengan wanita tidak hamil.

Hasil pada kedua kelompok menunjukkan bahwa kejadian hipotensi setelah pemberian anestesia spinal terjadi pada saat menit ke-3, dengan penurunan tekanan darah sebanyak 20\% dari tekanan darah awal (Tabel 1, Gambar 1). Pada menit ke-4 setelah pemberian NB dan NK tampak tekanan darah naik pada kedua kelompok dengan perbedaan sangat bermakna $(p=0,000)$. Kenaikan pada kelompok NB lebih terlihat daripada kelompok NK pada menit ke4, tetapi cenderung tidak stabil pada menit ke-5 sampai dengan menit ke-33, sehingga perlu diberikan tambahan pemberian norepinefrin bolus intravena pada beberapa subjek, lalu stabil setelah menit ke-36. Pada kelompok NK menunjukkan kenaikan tekanan darah lebih perlahan, tetapi cenderung semakin meningkat dimulai dari menit ke-9 sampai menit ke-33, lalu tekanan darah cenderung stabil pada saat menit ke-36 sampai akhir perlakuan. Keadaan ini menunjukkan bahwa norepinefrin memang mempunyai onset of action yang cepat dengan duration of action singkat, sehingga pemberian norepinefrin infus secara kontinu memerlukan dosis yang lebih besar sebagai loading dose sebelum dosis pemeliharaan, atau dosis kecil seperti yang dipergunakan pada penelitian ini dapat digunakan dalam tatalaksana preventif sebelum hipotensi terjadi, sedangkan pada pemberian bolus intravena memerlukan dosis berulang. Kedua cara pemberian norepinefrin ini tetap dapat diberikan dalam tatalaksana hipotensi pada anestesia spinal, karena pada pengujian statistika berdasarkan uji-t ANOVA pada masing-masing kelompok bila dilihat dari waktu ke waktu menunjukkan ada perbedaan bermakna $(p<0,005)$.

Laju nadi pada kedua kelompok perlakuan cenderung bradikardia saat setelah dilakukan anestesia spinal, terendah di menit ke-3, pada kelompok NB 58,45 $(2,69)$ dan kelompok NK 57,68 (1,96; Tabel 2; Gambar 2). Keadaan tersebut dikarenakan salah satu efek hipotensi pada anestesia spinal, terjadi blokade simpatis yang akan menyebabkan penurunan resistensi pembuluh darah perifer, aliran darah balik ke jantung serta curah jantung, hal ini disebabkan karena jumlah aliran darah balik ke jantung yang terlalu rendah serta bradikardia. ${ }^{11}$ Secara umum, nilai laju nadi pada kedua kelompok relatif stabil serta tidak terjadi bradikardia setelah menit ke-4 sampai selesai perlakuan, walau pada kelompok NB terjadi penurunan laju nadi sesaat pada menit ke-6, tetapi secara keseluruhan tidak menunjukkan perbedaan bermakna.

Kondisi di atas karena dosis norepinefrin yang dipakai pada penelitian ini adalah dosis kecil, sehingga efek kardiovaskular menjadi minimal. Pada pemberian norepinefrin dosis besar secara intravena terjadi vasokontriksi yang akan meyebabkan peningkatan resistensi pembuluh darah sistemik, penurunan aliran darah balik ke jantung, dan juga peningkatan tekanan darah sistol serta diastol secara tidak proposional sehingga terdapat rentang yang jauh. Hal ini mengakibatkan efek bradikardia yang disebabkan karena peningkatan stimulasi refleks baroreseptor vagal yang terdapat pada jantung. Penurunan aliran darah balik jantung yang dikombinasikan dengan stimulasi refleks baroreseptor yang menyebabkan bradikardia ditandai dengan peningkatan tekanan darah rata-rata walaupun terjadi penurunan curah jantung yang merupakan efek norepinefrin pada reseptor $\beta 1 .^{12,13}$

Nilai APGAR kedua kelompok perlakuan secara umum baik, hasil perhitungan statistika berdasarkan uji-t independen untuk inductiondelivery, uterine insicion-delivery time dan juga durasi pembedahan, yang dapat merupakan faktor pengganggu terhadap hasil nilai APGAR, menunjukkan perbedaan yang tidak bermakna ( $>0,05$; Tabel 3). Analisis nilai APGAR dengan Uji Mann-Whitney menunjukkan perbedaan 
yang tidak bermakna $(p>0,05)$, pada kelompok NB nilai APGAR 6 terjadi pada 1/22 bayi dan 4/22 bayi pada kelompok NK.

Kenyataan tersebut membuktikan bahwa keadaan hipotensi maternal walaupun singkat dapat mengganggu aliran darah uteroplasenta, sehingga dapat mengakibatkan penurunan nilai APGAR, bahkan mengakibatkan asidosis bila kejadian hipotensi maternal berlangsung lama. Hipotensi yang tidak lebih dari dua menit, hanya mengakibatkan asidosis janin minimal dan tidak akan memengaruhi neurobehavioral pada bayiyang baru saja dilahirkan. ${ }^{9}$ Pemberian vasopresor adalah tatalaksana penting untuk memperbaiki tekanan darah arteri rata-rata ibu. Pemeliharaan aliran darah uteroplasenta (uteroplacental blood flow/UBF) merupakan hal penting untuk kesejahteraan hidup janin. Uterine blood flow dapat dirumuskan sebagai berikut,

$$
\mathrm{UBF}=\frac{\mathrm{UAP}-\mathrm{UVP}}{\mathrm{UVR}}
$$

Keterangan: $\mathrm{UBF}=$ uterine blood flow $\mathrm{UVP}=$ uterine venous pressure $\mathrm{UAP}=$ uterine arterial pressure $\mathrm{UVR}=$ uterine vascular resistence

Semua keadaan yang menurunkan tekanan darah arteri rata-rata ibu atau meningkatkan UVR akan menurunkan UBF sehingga terjadi penurunan umbilical blood flow (UmBF). Nilai normal UBF adalah 2\% curah jantung, dalam kehamilan dapat meningkat sampai $20 \%$. Pada kehamilan aterm, $10 \%$ dari curah jantung atau $\pm 500-700 \mathrm{~mL} /$ menit akan memasok uterus sebanyak $80 \%$ akan memasuki plasenta. ${ }^{10,11}$

Induction-delivery time (ID) adalah jarak waktu yang dihitung sejak pemberian obatobatan anestesia sampai bayi lahir dan uterine insicion-delivery time (UD) adalah jarak yang dihitung dari mulai penyayatan uterus sampai bayi lahir. Terdapat banyak perbedaan pendapat mengenai perbandingan waktu optimaluntukID sertaUD terhadap nilai APGAR pada bayi yang dilakukan seksio sesarea dalam anestesi umum. Beberapa hasil penelitian menyatakan bahwa nilai APGAR tidak akan terganggu dan tidak terjadi asidosis pada bayi bila ID $<10$ menit serta UD $<3$ menit. Penelitian menunjukkan bahwa ID>30 menit serta UD>3 menit tidak memengaruhi nilai APGAR selama sepanjang jalannya pembedahan tidak terjadi hipotensi. Anestesia regional secara umum tidak memengaruhi ID serta UD, karena obatobatan yang diberikan tidak melalui plasenta serta mengganggu aliran darah uteroplasenta. Aliran darah uteroplasenta dapat terganggu pada anestesia regional, terutama anestesia spinal, karena angka kejadian hipotensi yang terjadi lebih tinggi. ${ }^{10}$

\section{Simpulan}

Pemberian norepinefrin bolus intravena dosis kecil ialah efektif, tetapi kadang harus diberikan berulang, sedangkan pada norepinefrin yang diberikan infus kontinu diperlukan dosis yang lebih besar sebagai loading dose sebelum dosis pemeliharaan, atau dosis kecil seperti yang digunakan pada penelitian ini dapat digunakan dalam tatalaksana preventif sebelum hipotensi terjadi. Kedua cara pemberian norepinefrin ini dapat digunakan dalam tatalaksana hipotensi anestesia spinal tanpa memengaruhi laju nadi dan juga nilai APGAR, karena menjaga tekanan darah ibu lebih penting supaya aliran darah uteroplasenta tetap terjaga.

\section{Daftar Pustaka}

1. Maayan-Metzger A, Schusnan-Eisen I, Todris L, Etchin A, Kuint J. Maternal hypotension during elective cesarean section and short term neonatal outcome. Am J Obstet Gynecol. 2010;202(56):1-5.

2. Ngan Kee WD. Prevention of maternal hypotension after regional anesthesia for caesarean section. Anaesthesiology. 2010;23:304-9.

3. Myhre JM. Review article: what's new in obstetric anesthesia?. Int J Obstet Anesth. 2011;20:149-59.

4. Tan HS, Sng BL. Review: control of blood pressure during spinal anesthesia for cesarean section. Trends Anesthesia Crit Care. 2013;3:166-70.

5. Lecoq H, Brichant F, Lamy L, Joris 
L. Norepinephrine and ephedrine do not counteract the increase in cutaneous microcirculation induced by spinal anaesthesia. $\mathrm{Br} \mathrm{J}$ Anaesth. 2010;105(2):214-9.

6. Minzter $\mathrm{BH}$, Johnson RF, Paschall RL, Ramasubramaniam R, Ayers GD, Downing JW. The diverse effects of vasopresors on the fetoplacental circulation of the dual perfused human placenta. Anesth Analg. 2009;10:1-6.

7. Goertz AW, Schmidt M, Seefelder C, Lindner $\mathrm{KH}$, Georgieff $\mathrm{M}$. The effect of phenylephrine bolus administration on left ventricular function during isofluraneinduced hypotension. Anest Analg. 1993;77:227-31.

8. Cohn JN. Comparative cardiovascular effects of tyramine, ephedrine, and norepinephrine in man. Circ Res.
1965;16:174-82.

9. Uyun Y, Adipraja K. Anestesi regional untuk seksio sesarea. Dalam: Bisri T, Wahjoeningsih S, Suwondo BS, penyunting. Anestesi obstetri. Edisi ke-1. Bandung: Saga Olah Citra; 2013. hlm. 57-8.

10. Datta S, Kodali BS, Segal S. Obstetric anesthesia handbook. Edisi ke-5. USA: Springer; 2010.

11. Montoya BH, Oliveros CI, Moreno DA. Managing hypotension induced by spinal anesthesia for cesarean section. Col Anest Mayo-Julio. 2009;37(2):131-40.

12. Katzung BG. Basic and cinical pharmacology. Edisi ke-10. San Francisco: McGraw-Hill; 2006.

13. Overgaard CB, Dzavik V. Inotropes and vasopresor: review of physiology and clinical use in cardiovacular disease. Circulation. 2008;118:1047-56. 